\title{
The Development of Physical and Psychological Training Models to Improve Football Performance
}

\author{
Asep Angga Permadi \\ Universitas Pendidikan Indonesia, Bandung, Indonesia \\ Universitas Garut, Indonesia \\ angga15@uniga.ac.id
}

\begin{abstract}
Sports Coaching is an activity or method that is useful for developing skills and abilities and increasing the capacity of human resources (HR). One way to achieve excellent physical condition is to do physical training that requires skills and awareness in sports. Football requires technical, tactical and physical skills to be very supportive in the performance of football players. Physical football training must be in accordance with the real position of the players in the match so that its performance is more optimal so that the coach can optimize the performance of all players, physical and mental elements (psychology) influence each other so that if both can be optimized, it can produce player performance (performance) better, The aim of this research is the development of physical and psychological training in football on the performance of football athletes. This research is a research and development $(R \& D)$ method, with the chosen development design adopting the development proposed by Borg and Gall consisting of 10 stages.
\end{abstract}

Keywords: physical training, sports psychology, performance, football

\section{INTRODUCTION}

Sports Coaching is an activity or method that is useful for developing skills [1] and abilities and increasing the capacity of human resources (HR). Sports coaching is a process of guided improvement and development in a single sport at identifiable stages of athlete development [2,3] Physical condition is a unified whole of physical components [4] that cannot be separated just like that, either improvement or maintenance. Physical condition is the ability to deal with the physical demands [5] of a sport to perform optimally [6]. Football requires technical, tactical [7-10] and physical skills [11-13] to greatly support the performance of football players [14]. Football physical training must be in accordance with the real position of the players $[15,16]$ in the match so that its performance is more optimal so that the coach can optimize the performance of all players in the team [17]. Football requires almost all components of physical conditions [18] because all are interdependent with each other in the technique of playing football [19].

In addition to physical conditions, football players must also be in a good psychological state. If we see, many psychological factors underestimated by an athlete or even a football coach. Young football players still have physical and mental limitations, must have stable psychology [20,21]. To qualified physical conditions and skills, athlete's appearance can be determined by several psychological factors including; achievement motives [22], intelligence, selfactualization, independence, aggressiveness, emotions, self- confidence [23]. There are many components in an athlete's mentality that determine a match and performance [24,25], including motivation, self-confidence, anxiety, aggressiveness, team cohesion, leadership, and many more. Mental (psychology) is a person's ability to think, imagine so as to enable the creation of better performance in playing football [26,27] while physical is an element that influences football skills and skills obtained from training results. Football players are required to play well and be able to deal with the pressures that occur in matches [28]. Physical and mental elements (psychology) affect each other so that if both of them can be optimized, it can produce better player performance, the performance of the contribution of tactics and mental techniques [29]. Based on the previous description, the researcher will conduct research that is focused on football players according to the position of players in the team in-depth with the existence of the football position training periodization program. This can be a new reference for coaches to solve problems in teams both individually and as a whole, based on a scientific study with the title Development of Physical Exercise and Psychology Models to Improve Football Player Performance.

\section{METHOD}

Related to the research that will be conducted more focused on developing physical and psychological training models to improve the performance of football players, the approaches and methods used in this research are research and development methods ( R \& D), with the development design chosen adopting from the development proposed by Borg and Gall consists of 10 stages [30]. However, the steps of the research and development model are not entirely carried out by researchers, because the focus is on developing a position football training model, not on the results of implementation. The development steps in this research will be divided into four global stages, namely: (1) the needs analysis phase (Literature Study and needs analysis), (2) the design development phase and the training model draft (3) the trial phase (Expert Test, small group trials, and large group tests), (4) Implementation of Models / Effectiveness Tests. This is in line with the problem of researchers who want to know the development of physical training models, namely the training position of players in football (goalkeeper, defender, midfielder, and forward), supported by the psychological factors of football including achievement motives, intelligence, actualization self, independence, aggressiveness, emotions and selfconfidence. In players, physical and mental (psychology) 
football to be made solutions and guidelines for football players who have good skills and participation in playing football contribute to the team with the training process can carry out individually and in a team so that players' performance on the field can be better suited to actual field conditions according to the player's position.

\section{CONCLUSION}

The development of physical and psychological training models in an effort to improve the performance of football players, in this study produced a product planning program periodization of training positions in the game of football making it easier for players to train individually and in teams to correct individual and team players' weaknesses and weaknesses. Gaining recognition from experts that the position training periodization program in football games is highly recommended to be a reference in the process of team and individual training. So that the position training program periodization products in football games are made in the form of books, and online application software to make it easier for the coaches to use or implement the positioning football training program so that players can increase their performance in playing football.

\section{ACKNOWLEDGMENT}

positions (goalkeeper, defender, midfielder and forward) is focused on the process of formulating the design of the model in the form of components of developing training models such as technique, training phase, training material, and process practice. In the development phase of the training model, the player's position in football (goalkeeper, defender, midfielder and forward) is accompanied by the procedure for implementation. To strengthen the development of the training model continued with the assessment and evaluation by the expert (Expert judgment) of the training model created.

\section{Validation, Evaluation, and Revision of Training Development}

In developing training through the process and results of trials or validation, the aim is to obtain input, suggestions and assessments through expert / panel / expert judgment research related to the development of training made. With the validation, evaluation, and revision flow of the training development are as follows: (Expert Judgment), Trials for small groups (Small Group Try-outs), and Trials for large groups (Field Try-outs)

\section{Implementation of Training Development}

At the implementation stage, the development of player's football practice exercises (goalkeeper, defender, midfielder and forward) to see the effectiveness of developing the position football training. So that the process of each stage that has been carried out, namely the implementation, training stages, equipment, progress, coaching points, and training areas in the development of position football training on the performance of players in the field is in accordance with the needs of players.

\section{DiscUSSION}

From the steps that have been carried out by researchers in accordance with the stages carried out so as to get a development of an alternative exercise in the problems in
This research is fully funded by the Institute of Education Fund Management (LPDP). I am very grateful to LPDP for their trust in funding this research. Hopefully, this research will be useful for the progress of sports development in Indonesia.

\section{REFERENCES}

[1] J. Côté, B. W. Young, J. North, and P. Duffy, "Towards a definition of excellence in sport coaching," Int. J. Coach. Sci., vol. 1, pp. 3-18, 2007.

[2] Excellence, C. (2012). International Sport Coaching Framework.

[3] J. Côté, M. Bruner, K. Erickson, L. Strachan, \& J. Fraser-Thomas, "Athlete development and coaching. Sports coaching: Professionalisation and practice," pp. 63-84, 2010.

[4] N. C. Wetzel, "Assessing the physical condition of children: III. The components of physical status and physical progress and their evaluation," The Journal of Pediatrics, vol. 22, no. 3, pp. 329-361, 1943.

[5] W. Helsen \& J. B. Bultynck, "Physical and perceptual-cognitive demands of top-class refereeing in association football," Journal of sports sciences, vol. 22, no. 2, pp. 179-189, 2004.

[6] R. Martens, Successful Coaching. United States: Human Kinetics, 2004.

[7] V. M. Kostiukevich, V. A. Stasiuk, N. Y. Shchepotina, \& A. A, Dyachenko, "Programming of skilled football players training process in the second cycle of specially created training during the year," Physical education of students, vol. 21, no. 6, pp. 262-269, 2017.

[8] A. J. Coutts, J. Quinn, J. Hocking, C. Castagna, \& E. Rampinini, "Match running performance in elite Australian Rules Football," Journal of Science and Medicine in Sport, vol. 13, no. 5, pp. 543548, 2010.

[9] C. Sullivan, J. C. Bilsborough, M. Cianciosi, J. Hocking, J. T. Cordy, \& A. J. Coutts, "Factors affecting match performance in professional Australian football," International Journal of Sports Physiology and Performance, vol. 9, no. 3, pp. 561-566, 2014.

[10] V. N. Shamardin, \& B. V. Khorkavyy, "Organizational structure of technical and tactical training of skilled goalkeepers in football," Pedagogics, psychology, medical-biological problems of physical training and sports, vol. 19, no. 2, pp. 75-79, 2015. 
[20] K. Natalia, "Psycho-Pedagogical Support in the Preparation of Young Football Players," Procedia - Social and Behavioral Sciences, vol. 185, pp. 286-289, 2015.

[11] S. V. Hill-Haas, B. Dawson, F. M. Impellizzeri, \& A. J. Coutts, "Physiology of small-sided games training in football. Sports medicine," vol. 41, no. 3, pp. 199-220, 2011.

[12] T. Kempton, C. Sullivan, J. C. Bilsborough, J. Cordy, \& A. J. Coutts, "Match-to-match variation in physical activity and technical skill measures in professional Australian Football," Journal of Science and Medicine in Sport, vol. 18, no. 1, pp. 109-113, 2015.

[13] H. Sarmento, R. Marcelino, M. T. Anguera, J. CampaniÇo, N. Matos, \& J. C. LeitÃo, "Match analysis in football: a systematic review," Journal of sports sciences, vol. 32, no. 20, pp. 1831-1843, 2014.

[14] R. M. Ruivo, A. I. Carita, \& P. Pezarat-Correia, "Effects of a 16-week strength-training program on soccer players," Science and Sports, pp. $1-7,2015$.

[15] T. A. Miller, E. D. White, K. A. Kinley, J. J. Congleton, \& M. J. Clark, "The effects of training history, player position, and body composition on exercise performance in collegiate football players," Journal of Strength and Conditioning Research, vol. 16, no. 1, pp. 4449, 2002.

[16] V. D Salvo, \& F. Pigozzi, "Physical training of football players based on their positional roles in the team," Journal of Sports Medicine and Physical Fitness, vol. 38, no. 4, pp. 294-297, 1998.

[17] T. Journal, V. D. Salvo, \& F. Italico, "Physical training of football players based on their positional rules in the team," 1997.

[18] A. Bolotin, \& V. Bakayev, "Pedagogical conditions necessary for effective speed-strength training of young football players (15-17 years old)," Journal of Human Sport and Exercise, vol. 12, no. 2,, pp. 405-413, 2017.

[19] M. Mooney, B. O'Brien, S. Cormack, A. Coutts, J. Berry, \& W. Young, "The relationship between physical capacity and match performance in elite Australian football: a mediation approach. Journal of Science and Medicine in Sport," vol. 14, no. 5, pp. 447452, 2011.
[21] J. O. Reilly, \& S. H. Wong, "ScienceDirect Effect of a carbohydrate drink on soccer skill performance following a sport-specific training program," Journal of Exercise Science \& Fitness, vol. 11, no. 2, pp. 95-101, 2013.

[22] C. Zuber, \& A. Conzelmann, "The impact of the achievement motive on athletic performance in adolescent football players," European journal of sports science, vol. 14, no. 5, pp. 475-483, 2014.

[23] G. Tenenbaum \& R. C. Eklund. Handbook of Sport Psychology, New Jersey: John Wiley \& Sons, Inc, 2007.

[24] P. J. Kremer \& D. B. Marchant, "Reflections and considerations of providing sport psychology services with professional football players," Science and football vol.4, pp. 294-299, 2002.

[25] M. Barker, T. J. Wyatt, R. L. Johnson, M. H. Stone, H. S. O'Bryant, C. Poe, \& M. Kent, "Performance factors, psychological assessment, physical characteristics, and football playing ability," The Journal of Strength \& Conditioning Research, vol. 7, no. 4, pp. 224-233, 1993.

[26] C. Viorel, Ş. Tüdös \& P. Radu, "Intersegmental coordination and the performance of junior football players," vol. 174, pp. 1666-1670, 2015.

[27] T. Reilly, G. Atkinson, B. Edwards, J. Waterhouse, K. Farrelly, \& E. Fairhurst, "Diurnal variation in temperature, mental and physical performance, and tasks specifically related to football (soccer)," Chronobiology International, vol. 24, no. 3, pp. 507-519, 2017.

[28] A. Mageau, A. J. Elliot, \& R. J. Vallerand, "Passion and performance attainment in sport," vol. 9, pp. 373-392, 2008.

[29] M. Kinchington, K. Ball, \& G. Naughton, "Physical Therapy in Sport Relation between lower limb comfort and performance in elite footballers," Physical Therapy in Sport, vol. 13, no. 1, pp. 27-34, 2012.

[30] W.R. Borg, W.R. \& M. D. Gall, Educational Research: An Introduction, New York: Longman, 2007. 